\title{
Status of Information and Communication Technology (ICT) in Health Profession Education in Kenya
}

Antony Otieno ${ }^{1}$, Steven Gachoka ${ }^{2}$, Edalia Hillary ${ }^{3}$, Faith Juma ${ }^{1}$, Martin Maingi ${ }^{4}$, Saidi Mugire $^{5}$, Samuel Mwangi ${ }^{2}$, Collins Yallah ${ }^{2}$, Kathleen B. Harrison ${ }^{6}$, John A. McNulty ${ }^{7}$ 1 Mount Kenya University, Thika, Kenya, Antonyotieno46@yahoo.com; faith.juma@yahoo.com

2. Kenya Methodist University, Meru, Kenya, stephenegachoka@yahoo.com; sirmwango60@yahoo.com

3. University of Nairobi, Nairobi, Kenya, edaliahillary@yahoo.com

4. Kenyatta University, Nairobi, Kenya , martinmaingi@yahoo.com

5. Catholic University of East Africa, Nairobi, Kenya, saidimugire@gmail.com

6. Project Harambee, NFP, Berwyn, IL, USA, Harambee.wor@sbcglobal.net

7. Leischner Institute of Medical Education, Loyola University Chicago , jmcnulty@lumc.edu

\begin{abstract}
Because ICT is an integral component of health care and education, we evaluated the status of ICT among health profession students $(n=310)$ at 5 universities in Kenya. Most students owned a computer $(73 \%)$ or smart phone $(60 \%)$. Ownership of ICT devices was significantly associated with familiarity of technology and Internet accessibility. Most students (54\%) agreed that computer instruction (CAI) was available in their curriculum, but only $39 \%$ used it routinely. Males were more familiar with ICT than females, which was the only important gender difference. These data and the variability in responses across universities provide important information for the continued development of policies to promote ICT in health education.
\end{abstract}

Indexing terms/Keywords:- Information Communication Technology; health education; Kenya; survey.

\section{Academic Discipline And Sub-Disciplines}

Health Profession

\section{SUBJECT CLASSIFICATION}

Education

\section{TYPE (METHOD/APPROACH)}

Survey/Interview

\section{Council for Innovative Research}

Peer Review Research Publishing System

\section{JOUrnal: INTERNATIONAL JOURNAL OF RESEARCH IN EDUCATION METHODOLOGY}

\author{
Vol 5, No. 2 \\ editor@cirworld.com
}

www.cirworld.com, member.cirworld.com 


\section{INTRODUCTION}

There is general agreement that Information and Communication Technology (ICT) provides numerous opportunities to enhance education, and the benefits of computer-aided instruction (e-learning) have been studied extensively as an aid to medical education (McNulty, Sonntag, \& Sinacore, 2009; Schifferdecker, Berman, Fall, \& Fischer, 2012). Although developing countries in Africa face serious challenges (e.g., shortage of electricity), there is a strong commitment to facilitate ICT in education at all levels (Farrell \& Isaac, 2007; Hennessy et al., 2010; Olson et al., 2011) and models to develop ICT educational polices are available (Zlotnikova \& van der Weide, 2012). In Kenya, a national ICT Master Plan has been adopted that includes education and health as priorities of social change (Kenya national ICT master plan 2017.2014). In addition, the Kenya Education Network (Kenya education network.2014), a separate national education and research network, is working to promote ICT in education and research at institutions of higher learning in Kenya.

A second priority of the Kenyan government is to ensure significant improvement in the status of health in Kenya (Chuma \& Okungu, 2011). Toward this end, ICT plays a critical role in accessing current health information and the broad applications that encompass the area of telemedicine (Ekeland, Bowes, \& Flottorp, 2010; Gatero, 2011). The use of ICT in accessing medical information was assessed earlier (Gituma et al., 2009) by surveying senior medical students at the University of Nairobi. At that time, only a small subset of students used the Internet routinely to access medical information hindered by slow Internet speed. More recently, a survey of administrations of medical schools in English speaking countries across Africa were found that infrastructure lagged behind other parts of the world, with only an estimated $15 \%$ of students in East Africa owning computers (Williams, Pitchforth, \& O'Callaghan, 2010).

In view of improved infrastructure supporting Internet access, we studied the status of ICT in health profession students at 5 universities in Kenya. The specific objectives of our study were to determine: 1) the extent of ownership of ICT-Internet capable devices; 2) the availability and level of access to the Internet; 3) the availability and use of ICT in curriculum; and 4) whether or not there are differences in use of ICT between genders and across universities.

\section{METHODS}

A survey was developed in consultation with students belonging to the International Health Care Student Association in Kenya. Printed copies of the survey were distributed to students studying in a variety of health profession programs (see Table 1) at five (5) universities, 3 of which are private and 2 public. The survey was intentionally brief to increase the level of voluntary participation. Responses to survey questions were based either on "yes/no" answers or on a Likert scale (1-5), and the results of the survey were transcribed into an Excel spreadsheet for sorting and analyses. Anonymity of respondents was maintained in accordance with standard practice. Universities are not identified in the analyses because it was not a purpose of the survey to make comparisons between specific institutions. Where appropriate, data were statistically evaluated by regression analysis and the Student's t-test.

\section{RESULTS}

A total of 310 surveys were returned from 149 females and 161 males at 5 universities (Table 1). Students were enrolled in different health profession programs with the most common being Clinical Medicine, Nursing and Bachelor of Medicine/Surgery (Table 1).

Table 1. Data on demographics of respondents. Number of females and males at each of the universities surveyed and the total number of students enrolled in specific clinical programs across all 5 universities. Numbers for clinical programs are not provided for each university in order to help preserve the anonymity of the universities.

\begin{tabular}{|c|c|c|c|c|c|}
\hline Demographics & Total & Univ A Univ B & Univ C & Univ D & Univ E \\
\hline Female & 149 & $29 \quad 35$ & 26 & 28 & 31 \\
\hline Male & 161 & 31 & 48 & 11 & 28 \\
\hline Clinical Medicine & 94 & & & & \\
\hline Nursing & 80 & & & & \\
\hline BachelorsMedicine/Surgery & 73 & & & & \\
\hline Pharmacy & 37 & & & & \\
\hline Clinical Health & 14 & & & & \\
\hline Other* & 9 & & & & \\
\hline
\end{tabular}

- $\quad$ includes psychology, medical laboratory, dental surgery.

Table 2 presents aggregate data according to gender on the results of student ownership of computers and smart phones, availability and access to the Internet, and use of ICT in their curricula. Responding to the question about level of familiarity with computer technology, fewer females (44\%) than males $(60 \%)$ described themselves as "very familiar". 
More students own computers (73\%) than smart phones (60\%) and in aggregate there are minimal gender differences in these figures. Students who had both a computer and a smart phone made up $48 \%$ of the respondents, but $15 \%$ did not own either a computer or a smart phone and there were minimal gender differences (Table 3 ). There was a significant correlation $(p<0.001 ; R=0.26)$ between student perceptions of familiarity with technology and their responses to how freely accessible the Internet was to them. The average Likert score for the response to familiarity of computer technology was significantly less $(p<0.001 ; t=6.94 \mathrm{df}=308 ; d=0.79)$ for those who did not have a computer $(x=2.90 ; n=84)$ compared with those who had a computer $(x=4.04 ; n=226)$. Similarly, the Likert score for the responses related to Internet accessibility were significantly less $(P<0.01 ; t=3.02 ; \quad d f=308 ; d=0.34)$ for those who did not have a computer ( $x=2.86$; $\mathrm{n}=84)$ compared with those who had a computer $(\mathrm{x}=3.34 ; \mathrm{n}=226)$.

\section{Table 2. Student responses to specific survey questions according to gender.}

\begin{tabular}{|c|c|c|}
\hline Survey Questions & $\%$ & $\%$ \\
\hline Percent of students who are "very familiar" with ICT & 52 & \\
\hline Female & & 44 \\
\hline Male & & 60 \\
\hline Percent of students who own a computer & 73 & \\
\hline Female & & 70 \\
\hline Male & & 75 \\
\hline Percent of students who own a smart phone & 60 & \\
\hline Female & & 62 \\
\hline Male & & 58 \\
\hline Percent of students who own neither computer nor smart phone & 15 & \\
\hline Female & & 17 \\
\hline Male & & 14 \\
\hline Percent of students who own both computer and smart phone & 48 & \\
\hline Female & & 50 \\
\hline Male & & 47 \\
\hline $\begin{array}{l}\text { Percent of students who agree or strongly agree that internet access is freely } \\
\text { available }\end{array}$ & 52 & \\
\hline Female & & 50 \\
\hline Male & & 55 \\
\hline Percent of students who access the internet 4 or more days per week. & 71 & \\
\hline Female & & 68 \\
\hline Male & & 74 \\
\hline Percent of students who have a Facebook page. & 94 & \\
\hline Female & & 95 \\
\hline Male & & 94 \\
\hline $\begin{array}{l}\text { Percent of students who agree or strongly agree that computer aided instruction is } \\
\text { available in their curriculum. }\end{array}$ & 54 & \\
\hline Female & & 52 \\
\hline Male & & 56 \\
\hline $\begin{array}{l}\text { Percent of students who used computer aided instruction } 4 \text { or more times per } \\
\text { week. }\end{array}$ & 39 & \\
\hline Female & & 39 \\
\hline Male & & 39 \\
\hline
\end{tabular}


Table 3. Percent of females and males who own computers and/or smart phones.

\begin{tabular}{|c|c|c|c|}
\hline Own computer & Own smart phone & \% Female & \% Male \\
\hline No & No & 17 & 11 \\
No & Yes & 13 & 29 \\
Yes & No & 21 & 47 \\
Yes & Yes & 50 & 14 \\
\hline
\end{tabular}

Table 4. Student responses on ICT ownership, familiarity with computer technology and presence on Facebook are divided according to each University in the survey and according to gender.

\begin{tabular}{|ccccccc|}
\hline Survey Questions & Univ A & Univ B & Univ C & Univ D & Univ E \\
\hline Percent who own a computer & 77 & 71 & 64 & 57 & 90 \\
\hline Female & 76 & 63 & 62 & 54 & 97 \\
\hline Male & 79 & 81 & 65 & 64 & 82 \\
\hline Percent who own a smart phone & 58 & 67 & 47 & 54 & 75 \\
\hline Female & 62 & 60 & 54 & 50 & 84 \\
\hline Male & 56 & 74 & 44 & 64 & 64 \\
\hline Percent "very familiar" with ICT & 61 & 55 & 43 & 36 & 59 \\
\hline Female & 58 & 51 & 34 & 25 & 48 \\
\hline Male & 65 & 58 & 48 & 64 & 71 \\
\hline Percent who have a Facebook page & 99 & 92 & 93 & 92 & 93 \\
\hline Female & 100 & 91 & 92 & 93 & 97 \\
\hline Male & 99 & 94 & 94 & 91 & 89 \\
\hline
\end{tabular}

Approximately $50 \%$ of the students "agreed or strongly agreed" with the statement that Internet access was freely available and more than $70 \%$ indicated they accessed the Internet 4 or more days per week. MOST students (94\%) stated they had a Facebook page. Survey questions related to ICT in the curriculum indicated that computer-aided instruction was available (54\% agreed or strongly agreed that computer aided instruction is available in their curriculum), but only $39 \%$ used computer aided instruction 4 or more times per week. Students who did not have computers and smart phones indicated on average that availability of the Internet was less, they accessed it less frequently, and they used computer aided instruction less (Tables 5, 6, 8).

Table 5. Percent of students who agree or strongly agree that the Internet is freely available. Percentages are provided for all students followed by a breakdown according to gender and according to whether students owned computers and smart phones.

\begin{tabular}{|lccccc|}
\hline Demographics & Univ A & Univ B & Univ C & Univ D & Univ E \\
\hline Overall & 67 & 43 & 41 & 67 & 49 \\
\hline Female & 73 & 29 & 38 & 64 & 45 \\
\hline Male & 63 & 58 & 42 & 73 & 54 \\
\hline Own computer & 73 & 49 & 48 & 73 & 47 \\
\hline Do not own computer & 50 & 26 & 27 & 59 & 67 \\
\hline Own smart phone & 74 & 50 & 51 & 67 & 48 \\
\hline Do not own smart phone & 60 & 32 & 31 & 73 & 53 \\
\hline
\end{tabular}


Table 6. Percent of students who reported they accessed the Internet 4 or more days a week. Percentages are provided for all students followed by a breakdown according to gender and according to whether students owned computers and smart phones.

\begin{tabular}{|lcccccc|}
\hline Demographics & Univ A & Univ B & Univ C & Univ D & Univ E \\
\hline Overall & 74 & 65 & 64 & 77 & 81 \\
\hline Female & 73 & 60 & 54 & 79 & 77 \\
\hline Male & 74 & 71 & 69 & 73 & 86 \\
\hline Own computer & 77 & 51 & 65 & 73 & 79 \\
\hline Do not own computer & 63 & 47 & 62 & 82 & 100 \\
\hline Own smart phone & 86 & 86 & 74 & 81 & 98 \\
\hline Do not own smart phone & 57 & 27 & 54 & 72 & 60 \\
\hline
\end{tabular}

Table 7. Percent of students who "agree" or "strongly agree" that computer aided instruction is available in their curriculum according to each university sampled. Percentages are provided for all students followed by a breakdown according to gender and according to whether students owned computers and smart phones.

\begin{tabular}{|lcccccc|}
\hline Demographics & Univ A & Univ B & Univ C & Univ D & Univ E \\
\hline Overall & 71 & 44 & 54 & 77 & 28 \\
\hline Female & 69 & 46 & 50 & 79 & 19 \\
\hline Male & 72 & 42 & 56 & 73 & 39 \\
\hline Own computer & 79 & 45 & 65 & 77 & 32 \\
\hline Do not own computer & 44 & 42 & 35 & 76 & 0 \\
\hline Own smart phone & 74 & 47 & 60 & 57 & 25 \\
\hline Do not own smart phone & 67 & 41 & 56 & 100 & 40 \\
\hline
\end{tabular}

Additional trends emerged when the data were examined according to University programs (Tables 4-8). There was considerable variability from university to university in the percent of students who owned ICT devices ranging between $54 \%$ and $90 \%$ (Table 4). Moreover, there was almost a $20 \%$ gender difference in ownership of computers and smart phones, which was reversed in some universities. For instance, ownership of smart phones was greater in males by $14 \%$ at University "B", whereas at University "E" more females owned smart phones by a margin of $20 \%$ (Table 4 ). A gender difference was especially large at University "D" where $64 \%$ of males described themselves as "very familiar" with computer technology compared to only $25 \%$ of females (Table 4 ).

Student responses on the availability of computer-aided instruction ranged between $17 \%$ and $79 \%$ across the universities (Table 7) and even fewer students indicated they used computer resources in the curriculum more than 4 days per week (Table 8). With few exceptions, students who do not own a computer or a smart phone tended to 1) feel the Internet is not freely available; 2) accessed the Internet less frequently; 3) feel that computer-aided instruction was less available; and 4) accessed computer-aided instruction less frequently (Tables 5-8). When the data from all universities were analyzed in aggregate, there was a statistically significant association between student ownership of computers and smart phones and their responses.

Table 8. Percent of students who use computer aided instruction $\mathbf{4}$ or more days a week. Percentages are provided for all students followed by a breakdown according to gender and according to whether students owned computers and smart phones.

\begin{tabular}{|lccccc|}
\hline Demographics & Univ A & Univ B & Univ C & Univ D & Univ E \\
\hline Overall & 48 & 38 & 32 & 54 & 22 \\
\hline Female & 42 & 41 & 29 & 64 & 13 \\
\hline Male & 53 & 33 & 34 & 30 & 33 \\
\hline Own computer & 53 & 47 & 47 & 50 & 22 \\
\hline Do not own computer & 38 & 13 & 1 & 60 & 25 \\
\hline Own smart phone & 58 & 55 & 41 & 53 & 26 \\
\hline Do not own smart phone & 32 & 16 & 24 & 56 & 10 \\
\hline
\end{tabular}




\section{DISCUSSION}

To our knowledge, this is the first in depth survey of the status of ICT among health profession students in Kenya. Our general conclusions are: 1) ICT use in professional health education programs has not reached its maximum phase; 2) there are few consistent gender differences; 3) ICT is not extensively integrated into the curricula of university programs; and 4) student perceptions of ICT availability vary across university programs.

Our findings can be placed in context with other recent ICT surveys. For example, a recent survey of Camaroon medical students reported that $78 \%$ used the Internet and that $17 \%$ did not own a computer (Bediang et al., 2013). These figures closely agree with the results of the present survey. Another survey found that only $15 \%$ of health care students in East Africa owned computers (Williams et al., 2010). A survey of township and rural schools in a marginalized community in South Africa found that $15 \%$ of students used computers daily with $17 \%$ having computers at home (Gunzo \& Dalvit, 2012). This use presumably included activities (e.g., games) not involving education and Internet access. More students (19-37\%) used cell phones to access the Internet and check email. In a survey of 4 Ghanaian universities, more than $50 \%$ of the students felt they were "proficient" or "expert" in computer skills (Coleman, 2011), which closely agrees with our findings. However, that study was based on a much smaller sample size $(n=73)$, and $75 \%$ of the respondents were male. A more comprehensive survey to measure computer literacy found that medical students in Sri Lanka had low to intermediate (approximately 50\%) computer literacy (Ranasinghe, Wickramasinghe, Pieris, Karunathilake, \& Constantine, 2012). More recently, a survey of Kenyan youth (ages 12-17) found that about $50 \%$ accessed the Internet daily (Gigii, 2013), in close agreement with our findings, but only about $22 \%$ used computers. It is noteworthy that a large percentage of students $(>94 \%)$ have a Facebook page, because it more accurately demonstrates their interest and presence on the Internet, and the importance of social media among students, even those who do not own ICT devices to access the Internet. Kenya has witnessed an explosion of the use of social media applications among youth (Gigii, 2013), due in large part to the rapid expansion in mobile phones (Bornman, 2012).

The device that has contributed extensively to expansion of ICT is the smart phone, which is defined as "a mobile phone built on a mobile operating system, with more advanced computing capability and connectivity than a basic feature phone" (Gigii, 2013). In this study, ownership of smart phones did not exceed that of computers, but almost $50 \%$ owned both, confirming the smart phone's importance to student activities (e.g., information from the Internet, collaborations, and use in social media). Smart phones have important potential for the establishment of virtual learning environments (Gopalan, Karavanis, Payne, \& Sloman, 2011), but they do not replace computers for many other educational needs (e.g., word processing). More than $60 \%$ of students enrolled in East Africa medical schools used computers for class assignments (Williams et al., 2010). While smart phones and other Internet-capable devices will continue to narrow the "digital divide" between Africa and other parts of the world, they cannot provide the complex functionality of broadband computer access to the Internet.

Because of its dynamic nature and rapid expansion, the availability and use of ICT in education (and society in general) require continual review and updating. A preliminary unpublished survey of health profession students ( $\mathrm{n}=69)$ at University "C" in 2009 revealed that only $35 \%$ owned a computer at that time, compared to $64 \%$ in the present survey. This near doubling of students who own computers is strong evidence of the increasing importance of ICT in education at this educational level. Student responses to the survey questions on the availability and use of computer-aided instruction suggest that e-learning is not widely available, is used sparingly, and varies significantly across university programs About two-thirds of students enrolled in health science training in Cameroon were not familiar with e-learning, though the majority of students perceived the value of e-learning to improve teacher/learner interactions $(>75 \%)$, collaborations $(>77 \%)$, and access to educational resources (>94\%) (Bediang et al., 2013). ICT offers numerous opportunities to address the challenges of implementing educational initiatives (Malapile \& Keengwe, 2013), although costs of implementation can be prohibitive aside from other barriers such as technical/human resources and teacher acceptance of ICT in the classroom (Pelgrum, 2001; Walters, 2011).

Overall, gender differences were most pronounced in response to the question about "familiarity" with ICT. More males than females stated they were "very familiar" with ICT even at University "E" where more females owned computers and smart phones. These findings agree with studies that have addressed gender effects showing that males exhibited greater stereotyping in computer behavior, computer access, and computer use (Imhof, Vollmeyer, \& Beierlein, 2007; Whitley, 1997).

The sampling of students from different universities revealed considerable variability in their responses, but there were no trends associated with attendance at public vs. private institutions. With the notable exception of students at University " $E$ ", those without a computer or smart phone tended to feel that the Internet was less freely available and they connected to the Internet less frequently. Because of the intentional brevity of our survey, we did not collect additional information on the ways students connected to and used the Internet. The Kenya Education Network (Kenya education network.2014) is currently surveying students at 30 universities across Kenya to include the perceptions of students and ICT usage.

There are several limitations of our study. First, as in any survey, the data are based on those students who elected to respond and may not represent the broader student population. A second limitation is the possibility that respondents interpreted questions differently. For example, the question related to "familiarity" with technology has considerable subjectivity. Similarly, students may have applied different definitions of a "smart phone", although the terminology and definition are relatively common. A third limitation is the brevity of our survey, as a number of important questions remain unanswered (e.g., what specific education activities are enhanced by ICT). As noted above, we elected to keep the survey short in order to increase the response rate. In view of these limitations, it is noteworthy that there 
were significant individual associations between a number of responses, which helps to validate the survey. For instance, the level of "familiarity" with technology depended significantly on whether students owned a computer.

\section{CONCLUSION}

this survey of the status of ICT in Kenyan health profession students provides important information for the continued development of policies to promote ICT in health education. The majority of students own ICT devices and almost all $(>95 \%)$ participate in social media using Facebook. The level of access to the Internet is variable from University to University as is the level of computer-aided instruction (e-learning). Although the task is not complete, the results show that Kenyan health care students are rapidly becoming equal partners in the information society.

\section{ACKNOWLEDGMENTS}

The survey was funded by Project Harambee, NFP (http://www.projectharambee.org/ help african women). We also wish to thank all the students who participated in the survey.

\section{REFERENCES}

1. Bediang, G., Stoll, B., Geissbuhler, A., Klohn, A. M., Stuckelberger, A., Nko'o, S., \& Chastonay, P. (2013). Computer literacy and E-learning perception in Cameroon: The case of Yaounde faculty of medicine and biomedical sciences. BMC Medical Education, 13, 57-6920-13-57. doi:10.1186/1472-6920-13-57; 10.1186/14726920-13-57

2. Bornman, E. (2012). The mobile phone in Africa: Has it become a highway to the information society or not? Contemporary Educational Technology, 3(4), 278-292.

3. Chuma, J., \& Okungu, V. (2011). Viewing the Kenyan health system through an equity lens: Implications for universal coverage. International Journal for Equity in Health, 10, 22-9276-10-22. doi:10.1186/1475-9276-10-22 10.1186/1475-9276-10-22

4. Coleman, R. K. N. (2011). Assessing the adoption of e-learning in Ghanaian universities. (Masters, Luleå University of Technology). 1-321.

5. Ekeland, A. G., Bowes, A., \& Flottorp, S. (2010). Effectiveness of telemedicine: A systematic review of reviews. International Journal of Medical Informatics, 79(11), 736-771. doi:10.1016/j.ijmedinf.2010.08.006; 10.1016/j.jmedinf.2010.08.006

6. Farrell, G., \& Isaac, S. (2007). Survey of ICT and education in Africa: A summary report, based on 53 country surveys. Washington, DC: InfoDev/ World Bank.

7. Gatero, G. (2011). Utilization of ICTs for accessing health information by medical professionals in Kenya: A case study of Kenyatta National Hospital. Journal of Health Informatics in Developing Countries, 5, 66-88.

8. Gigii, S. (2013). A (private) public space: Examining the use and impact of digital and social media among adolescents in Kenya, voices of youth citizens. Nairobi, Kenya: Africa.

9. Gituma, A., Masika, M., Muchangi, E., Nyagah, L., Otieno, V., Irimu, G., English, M. (2009). Access, sources and value of new medical information: Views of final year medical students at the University of Nairobi. Tropical Medicine \& International Health : TM \& IH, 14(1), 118-122. doi:10.1111/j.1365-3156.2008.02209.x; 10.1111/j.1365-3156.2008.02209.x

10. Gopalan, A., Karavanis, S., Payne, T., \& Sloman, M. (2011). Smartphone based e-learning. Proceedings of the 3rd International Conference on Computer Supported Education, Noordwijkerhout, Netherlands. 2

11. Gunzo, F., \& Dalvit, L. (2012). A survey of cell phone and computer access and use in marginalised schools in South Africa. Proceedings of M4D2012, New Delhi, India. 232-243.

12. Hennessy, S., Onguko, B., Harrison, D., Ang'ondi, E. K., Namalefe, S., Naseem, A., \& Wamakote, L. (2010). Developing the use of information and communication technology to enhance teaching and learning in East African schools: Review of the literature. ( No. 1). Eastern Africa: Centre for Commonwealth Education \& Aga Khan University Institute for Educational Development.

13. Imhof, M., Vollmeyer, R., \& Beierlein, C. (2007). Computer use and the gender gap: Issue of access, use, motivation, and performance. Computers in Human Behavior, 23(6), 2823-2837.

14. Kenya education network. (2014). Retrieved 3 February 2014, 2014, from http://www.kenet.or.ke/

15. Kenya national ICT master plan 2017. (2014). Retrieved 3 February 2014, 2014, from http://www.ict.go.ke/index.php/ict-masterplan/national-ict-masterplan-2017

16. Malapile, S., \& Keengwe, J. (2013). Information communication technology planning in developing countries. Education and Information Technologies, 1-11, doi:10.1007/s10639-013-9248-x.

17. McNulty, J. A., Sonntag, B., \& Sinacore, J. M. (2009). Evaluation of computer- aided instruction in a gross anatomy course: A six- year study. Anatomical Sciences Education, 2(1), 2-8. 
18. Olson, J., Codde, J., deMaagd, K., Tarkleson, E., Sinclair, J., Yook, S., \& Egideo, R. (2011). An analysis of elearning impacts and best practices in developing countries. East Lansing, MI: Michigan State University.

19. Pelgrum, W. J. (2001). Obstacles to the integration of ICT in education: Results from a worldwide educational assessment. Computers \& Education, 37(2), 163-178.

20. Ranasinghe, P., Wickramasinghe, S. A., Pieris, W. R., Karunathilake, I., \& Constantine, G. R. (2012). Computer literacy among first year medical students in a developing country: A cross sectional study. BMC Research Notes, 5, 504-512. doi:10.1186/1756-0500-5-504; 10.1186/1756-0500-5-504

21. Schifferdecker, K. E., Berman, N. B., Fall, L. H., \& Fischer, M. R. (2012). Adoption of computer-assisted learning in medical education: The educators' perspective. Medical Education, 46(11), 1063-1073. doi:10.1111/j.13652923.2012.04350.x; 10.1111/j.1365-2923.2012.04350.x

22. Walters, Z. C. (2011). Integration of technologies (ICTS) in teaching: Case of Buea University, Cameroom. (Masters, Universitet I Oslo). 1-109.

23. Whitley, B. E. (1997). Gender differences in computer-related attitudes and behavior: A meta-analysis. Computers in Human Behavior, 13(1), 1-22.

24. Williams, C. D., Pitchforth, E. L., \& O'Callaghan, C. (2010). Computers, the internet and medical education in Africa. Medical Education, 44(5), 485-488. doi:10.1111/j.1365-2923.2009.03602.x; 10.1111/j.13652923.2009.03602.x

25. Zlotnikova, I., \& van der Weide, T. (2012). An approach to modeling ICT educational policies in African countries. International Journal of Education and Development using ICT, 7(3), 50-73. 